\title{
ECOLOGICAL AND MICROGEOGRAPHICAL STUDY OF AN EPIKARSTIC FAUNA IN WEST VIRGINA (USA)
}

\author{
EKOLOŠKA IN MIKROGEOGRAFSKA RAZISKAVA \\ EPIKRAŠKE FAVNE V ZAHODNI VIRGINIJI (ZDA)
}

TANJA PIPAN ${ }^{1}$

${ }^{1}$ Karst Research Institute ZRC SAZU, Titov trg 2, p.p. 59, SI-6230, Postojna, Slovenia, e-mail: pipan@zrc-sazu.si 
Tanja Pipan: Ecological and microgeographical study of an epikarstic fauna in West Virgina (USA)

Drip pools and trickles of percolation water in 17 caves in West Virginia were sampled for epikarstic species. A total of 20 genera of copepods were found. 11 different genera of harpacticoids and 9 of cyclopoids were recognized in the samples collected from pools. For understanding of the structure and physico-chemistry of epikarst, the focus was specially on trickles rather than pools. Three sampling sites of the Organ cave system were chosen: the Lipps, Sively 2 and Sively 3 streams. All together in drips 13 genera of copepods, from which 8 of harpacticoids and 5 of cyclopoids have been found. Nearby drips have more similar fauna composition than distant drips. The epikarstic fauna will add significantly to the overall species richness found in Appalachian caves, and likely elsewhere in the U.S. as well.

Key words: fauna, percolation water, caves, epikarst, USA.

Izvleček

UDK: $551.44: 59(75-15)$ 595.34:551.44(75-15)

\section{Tanja Pipan: Ekološka in mikrogeografska raziskava epikraške favne v Zahodni Virginiji (ZDA)}

Za raziskavo epikraške favne so bili v Zahodni Virginiji v 17 jamah pobrani vzorci iz curkov ter luž napolnjenih s preniklo vodo. V lužah je bilo ugotovljenih 20 rodov ceponožcev, med njimi 11 harpaktikoidov in 9 ciklopoidov. Za razumevanje strukturnih ter fizikalnih in kemijskih lastnosti epikrasa je bil poudarek na raziskavi epikraške favne v curkih prenikajoče vode. Izbrana so bila tri vzorčna mesta v Organ jamskem sistemu: Lipps, Sively 2 in Sively 3 . V curkih je bilo najdenih 13 rodov ceponožcev, med njimi 8 harpaktikoidov in 5 ciklopoidov. Epikraška favna si je med bližnji curki bolj podobna, kot favna med oddaljenimi curki. Epikraška favna bo pomemben prispevk $\mathrm{k}$ pestrosti podzemeljske favne $\mathrm{v}$ jamah Apalačev, kot tudi $\mathrm{k}$ biodiverziteti ameriške favne.

Ključne besede: favna, prenikla voda, jame, epikras, ZDA. 


\section{INTRODUCTION AND BACKGROUND}

In May and June of 2004 I joined prof. Dr. David C. Culver (American University, Washington DC) and his colleagues Daniel W. Fong and Horton H. Hobbs III on an inventory project of the cave fauna of West Virginia. Overall, the purpose of this project was to inventory the cave fauna of more than 100 caves in southern West Virginia. In this study, also the epikarstic fauna sampling and studying was included, especially copepods. In addition, a longer term epikarst sampling has been set up in Organ cave system. This sampling involved sampling individual drips at different distances from each other in order to begin to understand the scale of differences. Besides collecting fauna, the parallel measurements of physical properties of the percolation water, and the beginning of the determining of the specimens were conducted.

At the beginning of this study, the extent and nature of the copepod fauna of the North American epikarst was almost completely unknown. The few records of copepods from North American caves are very occasional collections from streams and pools. A total of 4 stygobiontic cyclopoids and 2 harpacticoids have been reported from North American caves (Culver et al. 2000). The first preliminary study of epikarstic copepods was done in 2003 where drip pools in 13 caves in Virginia and West Virginia were sampled for epikarstic copepods. A total of 27 species were found, 11 of which are probably stygobionts (aquatic species found exclusively in subterranean habitats) (Brancelj et al. in review).

Research was aimed at unravelling the spatial structure of epikarstic fauna, specially copepods. Epikarst is the interface zone between soil and rock in karst landscape and is characterized by small fractures and solution pockets that may or may not be filled with water. It is an important zone for the transport of pollutants, an important water storage site and a habitat of high diversity of invertebrates (Jones 2003). According to rather few studies, the major part of the fauna in the epikarstic zones is represented by copepods (Pipan \& Brancelj 2003). Copepod crustaceans may be the most abundant metazoans on Earth and can be found in virtually every kind of aquatic habitat from the deepest ocean trenches to damp leaf litter at high altitude in the Himalayas and from hot springs to polar seas. They are frequently found in all kinds of hypogean habitats (Galassi 2001).

\section{EPIKARSTIC FAUNA IN POOLS}

In presented research I can report on the results of sampling drip pools in 17 caves in West Virginia for copepods and examine the diversity and pattern of this fauna. Drip pools were sampled for epikarstic species, using aspirators and fine-mesh nets designed to capture copepods and other minute invertebrates (Figure 1). A total of 20 genera of copepods were found. 11 different genera of harpacticoids and 9 of cyclopoids were recognized in the samples collected from pools. In addition to copepods there were also specimens of Nematoda, Gastropoda, Troglochaetus among Archiannelida, Oligochaeta, Acarina, Ostracoda, Bathynellacea, Isopoda, Amphipoda, Millipedia, Collembola, Coleoptera and insects larvae. Results of the correlation analyses indicate that there was correlation between copepod abundance and number of species on the one hand and the quantity of pumped water on the other hand $(\mathrm{p}<0.05)$. 


\section{EPIKARSTIC FAUNA IN TRICKLES}

For understanding of the structure and physical and chemical properties of epikarst, the focus was on trickles rather than pools. Microgeographic distribution studies were done in a short term field study in West Virginia where funnels were placed under drips for a period of approximately one month (Figure 2). Sampling and water chemistry measurements were undertaken at the sites at approximately 10-days intervals. The basic question was whether nearby drips are more similar than distant drips and whether drips in one cave are more similar than drips in different caves.

Three sampling sites of the Organ cave system were chosen (Stevens 1988): Lipps stream and in Organ cave passages Sively 2 and Sively 3. In the Lipps cave we had collection of 5 drips within 4 $\mathrm{m}$ of each other. In passages Sively 2 and Sively 3 we found 4 trickles in various distances, respectively. In the first case of Sively 2 the distance between the second and the fourth drip was around 7 $\mathrm{m}$, and the distance between the second and the fourth drips of Sively 3 was $1 \mathrm{~m}$. In both cases the distance between the first and the second drip was up to $200 \mathrm{~m}$. In the same cave system we had at least three clusters of distances - sets of drips less then $1 \mathrm{~m}$ apart, sets less then $10 \mathrm{~m}$ apart and sets of drips less then $200 \mathrm{~m}$ apart.

In samples collected from trickles the highest number of copepods was recorded in Lipps cave (222), whereas the highest number of different genera of copepods occurred in Siveley 3 (11). All together in drips we found 13 genera of copepods, from which 8 of harpacticoids and 5 of cyclopoids. The dominant copepod genera were Maraenobiotus, Microcyclops, and Bryocamptus.

Monitoring of trickles tens or hundreds of meters apart showed that there is a statistically significant negative correlation between the distance apart of the drips and the similarity of the fauna (using the Pearson correlation index: Davis 1973) ( $\mathrm{r}=-0.649, \mathrm{p} \leq 0.05)$. Taxa overlap among drips was generally low. The mean value for Jaccard index was 0.24 , and its maximum observed value was 0.80 . Only 13 pairs of drips (from 78 pairs) had a Jaccard index of 0.50 or higher.

Distant drips do not have a more similar fauna composition than nearby drips. But due to a horizontal and vertical moving of water in epikarst it is hard to say if each drip represents an isolated habitat or nearby drips come from the same habitat. The positive correlation of abundance and taxonomic richness $(r=0.67, \mathrm{p}<0.05)$ in drips imply substantial faunistic exchanges between microhabitats in epikarst.

The connections between total number of specimens and diversity on the one hand and temperature, conductivity, $\mathrm{pH}$, oxygen and drip rate on the other hand were calculated by means of Spearman correlation coefficient (Davis 1973). The positive correlation between number of specimens and diversity and discharge may reflect the general rule that epikarst represents a large habitat with a great number of species which may rival or exceed other karst zones. In the present study other physical properties, unless drip rate, not have been a crucial factor for the epikarstic copepod community.

These are preliminary results of the work that will continue for at least two years in USA and Slovenia where a comparison of ranges of epikarst and cave species will be done. The research is included in the bilateral project USA-Slovenia Cooperation in Science and Technology, supported by the Ministry of Education, Science and Sport (Slovenia) and Karst Waters Institute (USA). 


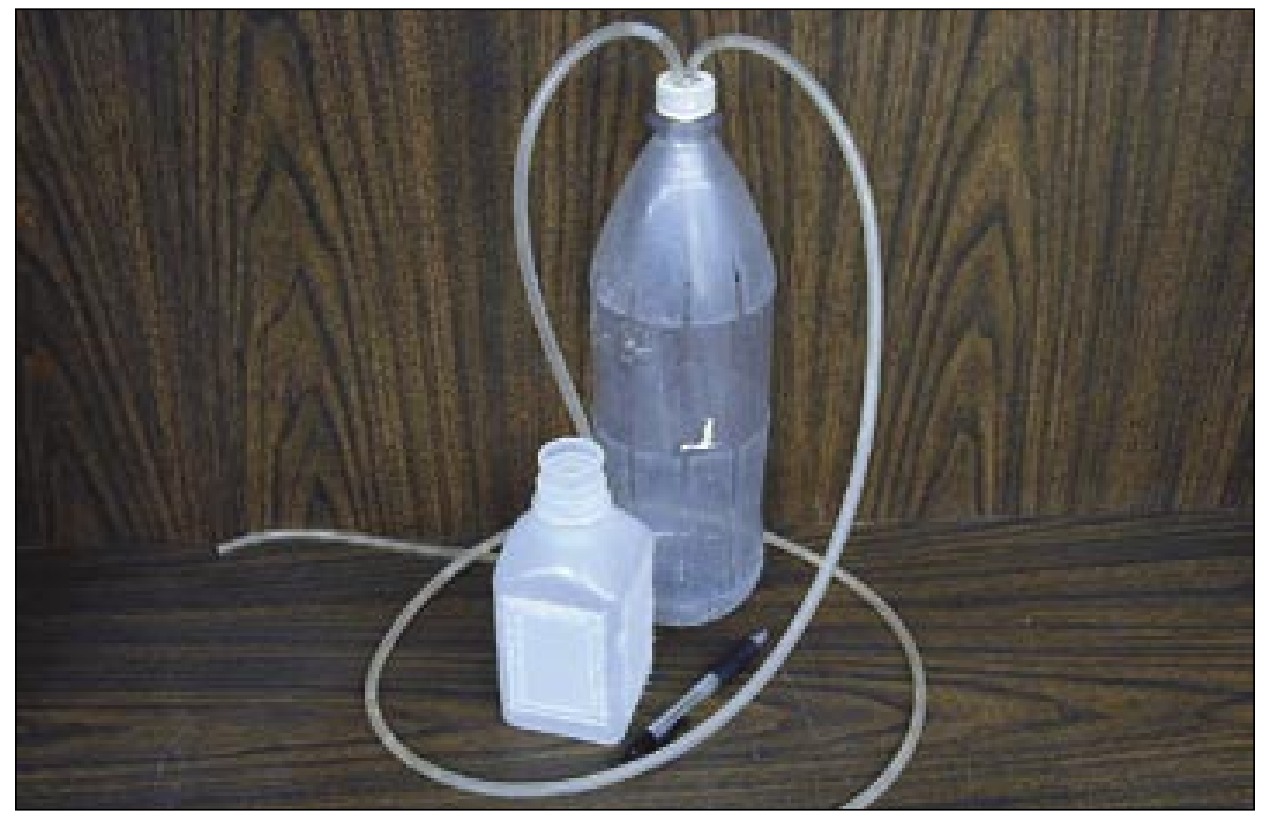

Fig. 1: Device for sampling pools (photo by D. Fong). Sl. 1: Naprava za vzorčenje luž (foto D. Fong).

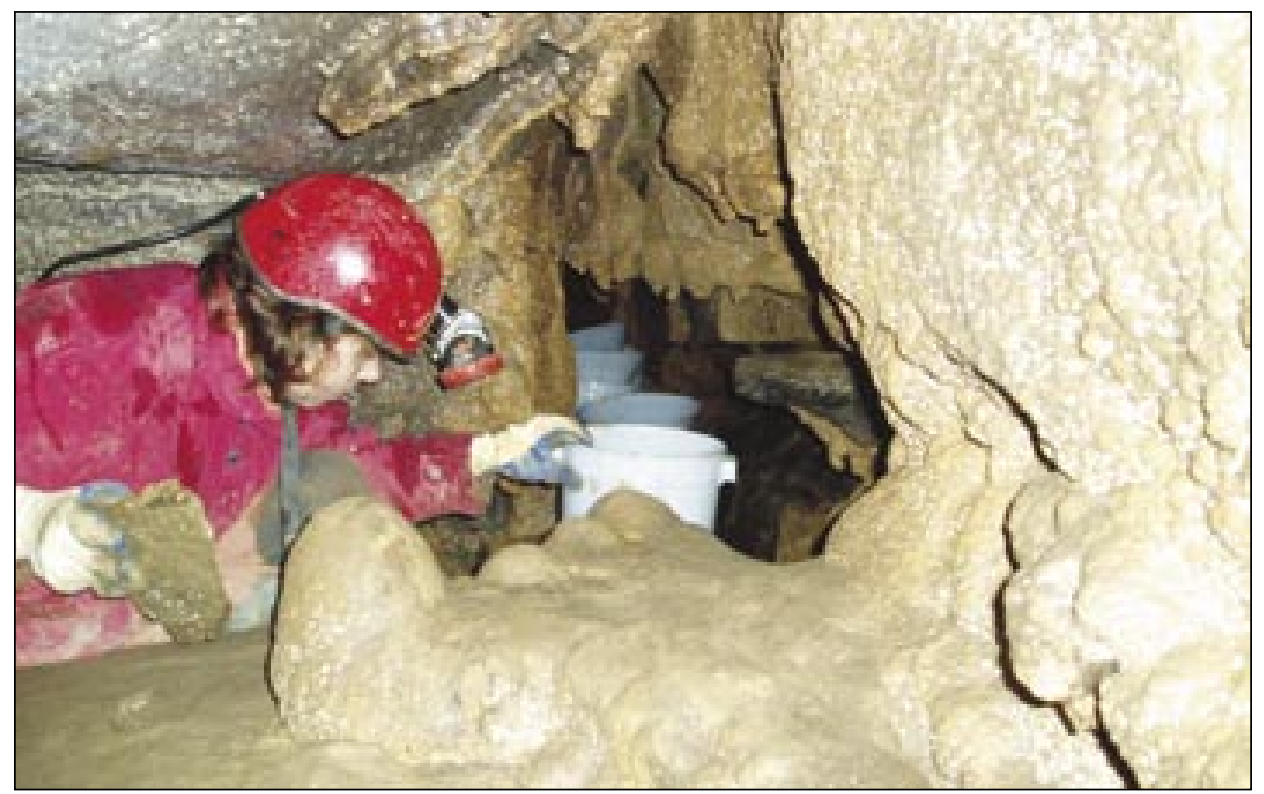

Fig. 2: Monitoring of trickles (photo by H. Hobbs III). Sl. 2: Monitoring curkov (foto H. Hobbs III). 


\section{ACKNOWLEDGEMENTS}

This work has been done in conjunction with a major cave macrofauna inventory in West Virginia in May and June of 2004, under the leadership of prof. David C. Culver. All of my expenses during my stay in the United States were covered by funds from the Karst Waters Institute (USA), including a round trip ticket from Ljubljana to Washington. I am indebted to prof. Culver for invitation to work in his project. I thank David Culver, Horton Hobbs III, Dan Fong, Katie Schneider, Jeff Hajenga, Dave Cowan who assisted at the field. I would like to thank head of the Karst Research Institute ZRC SAZU in Slovenia dr. Tadej Slabe and Sklad za mednarodno sodelovanje ZRC SAZU for financial support.

\section{REFERENCES}

Brancelj, A., T. Pipan \& D.C. Culver, (in review): Copepods in the Epikarst Zone of Caves - First Results for North American Caves.- Journal of Cave and Karst Studies

Culver, D.C., L.L. Master, M.C. Christman \& H.H. Hobbs III, 2000: Obligate cave fauna of the 48 contiguous United States.- Conservation Biology, vol. 14, 386-401

Davis, J.C., 1973: Statistics and Data Analysis in Geology.- New York, John Wiley \& Sons, Inc., 59-106, 456-473

Galassi, D.M.P., 2001: Groundwater copepods: diversity patterns over ecological and evolutionary scales.- Hydrobiologia, 453-454, 227-253

Jones, W.K., 2003: Introduction to Epikarst.- Epikarst: proceedings of the symposium held October 1 through 4, 2003, Sheperdstown, West Virginia, USA: Karst Waters Institute, 3-7

Pipan, T. \& A. Brancelj, 2003: The fauna of epikarst : Copepoda (Crustacea) in percolation water of Karst caves in Slovenia.- Annales, Ser. hist. nat., 13, 2, 223-228

Stevens, P., 1988: Caves of the Organ Cave Plateau, Greenbrier Country, West Wirginia.- Speleological Survey, Bulletin 9. 


\title{
EKOLOŠKA IN MIKROGEOGRAFSKA RAZISKAVA EPIKRAŠKE FAVNE V ZDA
}

\begin{abstract}
Povzetek
Favnistične in ekološke razmere epikraških habitatov so bile proučevane v 17 jamah Zahodne Virginije (ZDA). Raziskava je bila opravljena na pobudo prof. dr. Davida C. Culverja ter vključena $\mathrm{v}$ projekt inventarizacije podzemeljske favne $\mathrm{v}$ jamah Zahodne Virginije.

Epikras je prehodna cona med prstjo in matično kamnino. Osnovna značilnost epikrasa je velika heterogenost, kar pomeni, da se v številnih razpokah in špranjah voda zadržuje stalno ali le občasno. Poleg skladiščenja vode je epikras pomemben tudi kot področje, kjer polutanti prehajajo v nižje predele kraškega vodonosnika ter kot habitat z visoko pestrostjo nevretenčarjev (Jones 2003). Epikras je pomemben habitat podzemeljske favne, redkih in še neopisanih vrst, od katerih prevladujejo ceponožni raki. $\mathrm{V}$ dosedanjih raziskavah sta bili biodiverziteta ter ekologija favne v preniklih vodah kraških jam redko sistematično obravnavani. Prva preliminarna raziskava epikraške favne v Ameriki je bila opravljena v letu 2003, kjer so bile vzorčene luže z epikraško vodo (Brancelj et al. in review).

$\mathrm{V}$ prenikli vodi so bili poleg ceponožcev najdeni osebki 13 različnih taksonomskih skupin. V lužah in curkih je bilo skupno ugotovljenih 20 redov ceponožcev, med njimi 11 redov harpaktikoidov ter 9 redov ciklopoidov. Mikregeografska razporeditev vrst je bila proučevna z namenom odgovoriti na ključna vprašanja ali so si bližnji curki v jami favnistično bolj podobni in vodijo iz istega habitata, ter ali so si curki iz posamezne jame favnistično bolj podobni kot curki iz drugih jam. Izbrana so bila tri vzorčna mesta v jamskem sistemu in skupno 13 vzorčnih točk, ki so bila med sabo različno oddaljena (1 m - $200 \mathrm{~m})$. Okoljski parametri so bili spremljani z namenom ugotavljanja ekoloških razmer v prenikli vodi ter soodvisnosti epikraške favne in ekoloških parametrov. S korelacijsko analizo je bila ugotovljena velika raznolikost združb ceponožcev v prenikajoči vodi.
\end{abstract}


